\title{
Study the Potential Therapeutic Effect of Garden Cress (Lepidiumsativum) on Nephropathy Diabetic Rats: Biological and Biochemical Studies
}

\author{
Amal N. Z. Nasef and Basma R. M. Khateib ${ }^{1}$
}

\begin{abstract}
Garden cress powder (GCP) considered as an important medicinal plant and widely grown in several countries including Egypt. whereas it has a high content of phenolic compounds and antioxidant activity. The objective of this study were assessed the potential therapeutic effects of Garden cress on nephropathy induced by gentamicin in diabetic rats. Thirty adult male albino rats were divided into two main groups. Group I: negative control (6 rats) and group II(24 rats): nephropathy diabetic rats group were given a single dose via intraperitoneal injection of $65 \mathrm{mg} / \mathrm{kg}$ body weight of streptozotocin (STZ). Then, nephropathy was induced in diabetic rats via intraperitoneally injection daily of gentamicin (GM) $85 \mathrm{mg} / \mathrm{kg}$ body weight for 8 days. Nephropathy diabetic rats group were divided into four subgroups (6 rats each) as follow: First (control positive group), second, third and fourth group received basal diet with $5,7.5$ and $10 \%$ of GCP, respectively. Results showed that GCP contained high amount of potassium(2950.36 g/100g), Phosphorus (944.33 g/100g), and phenolics compounds as gallic $(3010.75 \mu \mathrm{g} / 100 \mathrm{~g})$, ellagic $(1466.92$ $\mu \mathrm{g} / \mathbf{1 0 0 g})$, protocatechuic $(588.23 \mu \mathrm{g} / 100 \mathrm{~g})$, chlorogenic $(556.75 \mu \mathrm{g} / 100 \mathrm{~g})$, coumarin $(519.52 \mu \mathrm{g} / 100 \mathrm{~g})$ and isoferulic( $545.34 \mu \mathrm{g} / \mathbf{1 0 0 g})$. Feeding nephropathy diabetic rats on a daily diet containing powder of garden cress with 5, 7.5 and $10 \%$ of standard diet produced a marked reduction in the serum levels of glucose, liver and kidney functions and malondialdehyde ( MDA) levels as well as elevation in the activity of glutathione transferase( GST), superoxide dismutase (SOD), total antioxidant capacity (TAC), glutathione pyroxidase (GPX) and catalase (CAT ) and serum insulin levels compared to positive control group. While, supplemented diet rats with $10 \%$ of GCP was more effective in improving the previous parameters.

In conclusion, The study concluded that garden cress powder has hypoglycemic potent effects and improve renal damage induced by gentamicin in diabetic rats. So it is advice to add GCP to daily diet for kidney patients.
\end{abstract}

Keywords:Garden cress, nephropathy, streptozotocin, gentamicin, glucose, kidney function , Antioxidants, insulin, urea.

\section{INTRODUCTION}

Diabetes mellitus (DM) is a one of chronic metabolic disease characterized by chronic hyperglycemia with turmoil in the metabolism of carbohydrates, protein and fat induced insufficiency of insulin secretion or decreased sensitivity of the target tissues to insulin (Omolaoye et al., 2018). Chronic hyperglycemia linked with high morbidity and mortality due to cumulative damage and severe health complications in most tissues and organs, involve kidneys, heart, blood vessels, eyes, nerves and skin (Kahn et al., 2014). Moreover, the progression and aggravation of oxidative stress produced by the impaired metabolism which appears through several mechanisms, such as glucose autoxidation, protein glucation resulting in the development of diabetic complications as nephropathy causing renal failure, retinopathy leading to blindess, neuropathy, macro and microvascular damage and sexual dysfunction (WHO, 2016).

Diabetes produces excess reactive oxygen species which damage the capillaries in the kidney's glomeruli leading to diabetic nephropathy (Kittell, 2012). Also, the kidney is influenced by some drugs like gentamicin, which is known for its nephrotoxicity (Nale et al., 2012) and accumulation of gentamicin in renal tubular cells causes apoptosis, necrosis and demolition of cells (Dontabhaktuni et al., 2016 ).

Diabetic nephropathy is one of the most serious complications of diabetes and the most common cause of end-stage renal failure. At present, diabetic kidney disease affects about $15 \%-25 \%$ of type I diabetes patients (Hovind et al., 2003). Reactive oxygen species (ROS) play an important role in high glucose-induced renal injury (Ha and Lee, 2000) .

Medical plants have been used as therapeutic agents in traditional system. Before the advent of insulin and oral hypoglycemic drugs, the major form of treatment involved the use of parts of plants (Chauhan et al., 2012).

Current therapeutic strategies for diabetic nephropathy are aimed at management and alleviation of the underlying pathological processes and include lifestyle modifications such as healthy diet, weight control and regular physical activity coupled with medication/drug interventions (Tran et al., 2015).

DOI: 10.21608/asejaiqjsae.2021.165932

${ }^{1}$ Dept. of Nutrition \& Food Science, Faculty of Home Economics,

Menoufia University, Egypt.

Corresponding Author: amal_nasef2010@yahoo.com

Tel: 01020608340

Received March 10, 2021, Accepted, April 23, 2021. 
Garden cress (GC) Lepidium sativum is rich in proteins, vitamins, minerals, especially calcium and iron and contain $24 \%$ fat in which $34.5 \%$ of total fatty acids $\alpha$-linolenic acid.The seeds are wealthy phenolic compounds and have high antioxidant activity compared to other cress varieties. It contains many phytochemicals with potential nutraceutical activity like glucosinolates, flavonoids, coumarins, sulphur glycosides, triterpenes, sterols and various imidazole alkaloids (Maier et al., 1998 and Bryan et al., 2009).

Flavonoids are abundant plant phenolic compounds. More than 6000 have been identified, and some have shown to possess hypoglycemic and antidiabetic activities (Sharma et al., 2008).

In Unani system of medicine, seed powders and leaves of (GC) have been reported to possess diuretics, aperients and aphrodisiac properties and are recommended in inflammation, bronchitis, rheumatism and muscular pain. It is also reported to be useful in the treatment of asthma, cough and bleeding piles (Eddouks et al., 2005).

The plant is also reported to possess antihemoglutinating, hypoglycemic, antihypertensive, diuretic, fracture healing properties and significant bronchodilatory activities (Chauhan et al., 2012).

GC seeds shows many medicinal properties such as antidiabetic, hypocholesterolemic, antihypertensive, antidiarrheal, antispasmodic and laxative activities, it also has fracture healing hepato protective, diuretic, ant inflammatory, nephron protective enephrocurative, galactogogue ,antipyretic and analgesic potential ( Gokavi et al., 2004).

Diabetic and hyper lipidemic rats administered with GC seed showed a significant decrease in fasting blood glucose levels, glycosylated haemoglobin, lipid profile, total cholesterol, triglycerides and lipoprotein fractions (Chauhan et al., 2012).

Therefore, the objective of this study were assessed the potential therapeutic effects of garden cress (GC) L.sativum on nephropathy induced by gentamicin in diabetic rats.

\section{MATERIALS AND METHODS}

\section{Materials:}

\section{Garden cress}

(GC) seed was obtained from the local market of Shibin-El kom City -Menoufia governorate Egypt.

\section{Chemicals}

Gentamicin (GM) sulfate was obtained from Memphis Company, For Pharm. \& Chem. Ind. -Cairo. Streptozotocin (STZ) was obtained from Sigma-Aldrich Inc. Kits for estimating biochemical analysis were purchased from Alkan Medical Company, El-Doky, Giza, Egypt. Malondialdehyde (MDA), catalase (CAT), glutathione peroxidase (GSH.Px) and superoxide dismutase (SOD) activity Kits were obtained from Biodiagnostic Company, El-Doky, Giza, Egypt.

\section{Animals}

Thirty adult male albino rats, Sprague Drawley strain, weighing $(180 \pm 5 \mathrm{~g})$ were obtained from Medical Insects Research Institute, El-Doky, Giza, Egypt. Rats were housed individually in well aerated cages under hygienic laboratory condition in Laboratory, Faculty of Home Economics, , ShibinEl-kom, Menoufia, Egypt and fed standard diet according to AIN-93 guidelines (Reeves et al., 1993), for 7 days as an adaptation period.

\section{Methods:}

\section{Experimental design:}

Rats were randomly divided into two main groups. The first group, normal control $(n=6)$. The second group: nephropathy diabetic rats $(n=24)$ were given a single dose via intraperitoneal injection of $65 \mathrm{mg} / \mathrm{kg}$ body weight of streptozotocin (STZ) dissolved in a freshly prepared $0.01 \mathrm{M}$ citrate buffer (PH 4.5) according to Yanardag et al., (2003). Diabetes was identified by polydipsia, poly-urea (visual observations) and measuring fasting blood glucose level after $72 \mathrm{~h}$ of injection of STZ. Rats with a fasting blood glucose level above $200 \mathrm{mg} / \mathrm{dl}$ were considered diabetic and were used in this study. Then, Nephropathy was induced in diabetic rats via intraperitoneally injection daily of gentamicin (GM) $85 \mathrm{mg} / \mathrm{kg}$ body weight for 8 days as described by Jeyanthi and Subramanian (2009). Nephropathy diabetic rats group were divided into four subgroups (6 rats each) as follow: First (positive control group), second, third and fourth group received standard diet plus 5, 7. 5 and $10 \%$ of GCP respectively for 30 days. At the end of the experimental period (30 day), rats were anesthetized with diethyl ether after fasting for $12 \mathrm{~h}$ and blood samples were collected from the hepatic portal vein and centrifuged to obtain serum .

\section{Biological evaluation:}

During the experimental period (30 day), the consumed feeding was recorded every day, body weight gain (BWG\%) and feed efficiency ratio (FER) were calculated according to Chapman et al., (1959) using the following equations: 
Body weight gain $(\mathrm{BWG} \%)=$

(Final weight-Initial weight)

X 100

Initial weight

$$
\text { Feed efficiency ratio }(\text { FER })=\frac{\text { Gain in body weight }(\mathrm{g})}{\text { Feed intake }(\mathrm{g}) / 30}
$$

\section{Chemical Analysis:}

Moisture, protein, fat, fiber and ash contents of GC were determined according to methods described by the AOAC (2010). Carbohydrates contents were estimated by difference.

Determination of minerals contents were determined according to the method of AOAC (2005). Determination of Phenolic compounds of GC extract were determined according to (Goupyet al. 1999).

\section{Biochemical analysis:}

The serum levels of glucose was determined according to Trinder (1969). Insulin was estimated according to(Cordero-Herreraet al., 2015). Urea, creatinine and uric acid levels were estimated according to Trinder, (1969); Tietz, (1986) and Fossati et al., (1980), respectively. BUN was estimated according to (Philip, 1994).

Aspartate aminotransaminase(AST) and alanine aminotransferase (ALT) were measured by according to method described by Henry, (1974) and Yound, (1975), respectively. Also alkaline phosphatase (ALP), was estimated according the method of IFCC, (1983). Glutathione peroxidase (GPX), superoxide dismutase (SOD), catalase (CAT), glutathione s-transferases (GSTs), total antioxidant capacity (TAC) and malondialdehyde (MDA) were measured by method of Zhao et al., (2001); Sun et al., (1988); Diego,(2011); Hegsted et al., (1941); Koracevic et al., (2001); Satoh, (1978) and Ohkawa et al., (1979), respectively.

\section{Statistical analysis}

Results were expressed as the mean \pm SD. Data for multiple variable comparisons were analyzed by oneway analysis of variance (ANOVA). For the comparison of significance between groups, Duncan's test was used as a post hoc test according to the statistical package program (Artimage and Berry, 1987).

\section{RESULTS AND DISCUSSION}

Chemical composition of GC was presented in table (1) data showed that protein (21.61) $\mathrm{g} / 100 \mathrm{~g}$, carbohydrate (27.80) g/100g, fat (32.28) $\mathrm{g} / 100 \mathrm{~g}$ and fiber $(6.75) \mathrm{g} / 100 \mathrm{~g}$ were high in $\mathrm{GC}$ while moisture (6.73) $\mathrm{g} / 100 \mathrm{~g}$ and ash (4.83) g/100g were low. These results show that the macronutrients are considerably high for human nutrition. in addition, the above findings are almost in accordance with the outcomes reported by Doke and Guha (2017) who reported that the garden cress seeds contain $25 \%$ of protein, $14-24 \%$ of lipids, $33-54 \%$ of carbohydrates and $8 \%$ of crude fiber. Zia-UlHaq et al. (2012) observed that the proximate chemical composition of GC was $2.9 \%, 23.2 \%, 24.2 \% 30.7 \%$, $11.9 \%$ and $7.1 \%$ for moisture, crude fat, protein,carbohydrate, fiber and ash, respectively.

Table 1. Chemical composition of GCP g/100g dry weight

\begin{tabular}{cc}
\hline $\begin{array}{c}\text { Constituent of } \\
\text { GCP }\end{array}$ & g/100g \\
\hline Moisture & 6.73 \\
Crude protein & 21.61 \\
Fat & 32.28 \\
Crude fiber & 6.75 \\
Ash & 4.83 \\
Total carbohydrate & 27.80 \\
\hline
\end{tabular}

Content of minerals of GCP is presented in table 2 data showed that GCP has high content of potassium $2950.36 \mathrm{mg} / 100 \mathrm{~g}$ and Phosphorus 944.33 $\mathrm{mg} / 100 \mathrm{~g}$, While contained a medium quantity of calcium $210.23 \mathrm{mg} / 100 \mathrm{~g}$, sodium $230.35 \mathrm{mg} / 100 \mathrm{~g}$ and Magnesium $325.00 \mathrm{mg} / 100 \mathrm{~g}$. finally, zinc $2.96 \mathrm{mg} / 100 \mathrm{~g}$ was low. Shail et al. (2016) and Doke and Ghua (2017) reported that GC seeds are a good source of minerals such as, phosphorus magnesium and potassium.

Table 2. Minerals content of GCP $\mathbf{~ m g / 1 0 0 g}$

\begin{tabular}{cc}
\hline Minerals of GC & g/100g \\
\hline Potassium $(\mathrm{K})$ & 2950.36 \\
Calcium $(\mathrm{Ca})$ & 210.23 \\
Phosphorus(P) & 944.33 \\
Magnesium $(\mathrm{Mg})$ & 325 \\
Sodium $(\mathrm{Na})$ & 230.35 \\
Zinc $(\mathrm{Zn})$ & 2.96 \\
\hline
\end{tabular}


Data in table (3) show that a phenolic compounds in GC It is clear to notice that the highest phenolics compounds of GC extract recorded for gallic, ellagic, protocatechuic, chlorogenic, coumarin and Iso- ferulic. The values were $3010.75,1466.92,588.23,556.75$, 519.52 and $545.34 \mathrm{mg} / 100 \mathrm{~g}$, respectively. All of these play an important role in improving the human health by participating in the antioxidant defense system against free radical generation. These results are in agreement with Zia-Ul-Haq et al. (2012) and Ait Yahia et al. (2018).

And also Sethiya et al., 2014 who reported Gallic acid and Protocatechuic acid are phytochemicals that are considered to be a potential source of functional food ingredients for their high antioxidant capacity.
Flavonoids are abundant plant phenolic compounds more than 6000 have been identified, and some have shown to possess hypoglycemic and antidiabetic activities (Sharma et al., 2008).

Data presented in Table (4) illustrate the effect of GCP on BWG, FI and FER of nephropathy diabetic rats. It could be observed that the mean value of BWG, FI and FER of positive control group significantly $(\mathrm{P} \leq 0.05)$ decreased in nephropathy diabetic rats compared to normal control rats these results are in agreement with (Wang et al., 2011) who reported that diabetes was associated with reduced body weight when compared with the control rats. More over nephropathy diabetic rats supplemented with $5,7.5$ and $10 \%$ of GCP resulted in increase $(\mathrm{P} \leq 0.05)$ in $\mathrm{BWG}$, FI and FER compared with positive control rats.

Table 3. phenolic compounds in GC extract

\begin{tabular}{cc}
\hline phenolic compounds & $(\boldsymbol{\mu g} / \mathbf{1 0 0 g})$ \\
\hline Gallic & 3010.75 \\
Pyrogallol & 6.99 \\
4-Aminobenzoic & 128.88 \\
Protocatechuic & 588.23 \\
Catechein & 108.61 \\
Chlorogenic & 556.75 \\
Catechol & 177.74 \\
Caffiene & 215.55 \\
P.oH. benzoic & 28.85 \\
Caffeic & 248.30 \\
Vanillic & 425.79 \\
p-Coumaric & 115.86 \\
Ferulic & 79.40 \\
Iso- ferulic & 545.34 \\
Ellagic & 1466.92 \\
Benzoic & 276.76 \\
$\alpha-$ Coumaric & 37.77 \\
3,4,5.Methoxy Cinnamic & 83.04 \\
Coumarin & 519.52 \\
Salicylic & 73.50 \\
Cinnamic & 114.965 \\
\hline
\end{tabular}

Table 4. Effect of GCP on body weight gain (BWG\%), feed intake (FI) and feed efficiency ratio (FER) of nephropathy diabetic rats

\begin{tabular}{cccccc}
\hline \multirow{2}{*}{ Groups } & \multirow{2}{*}{$\begin{array}{c}\text { Normal } \\
\text { Control }\end{array}$} & $\begin{array}{c}\text { Positive } \\
\text { Parameter }\end{array}$ & Control & \multicolumn{3}{c}{ Nephropathy Diabetic Rats } \\
\cline { 4 - 6 } & & & $\mathbf{5 \%}$ & $\mathbf{7 . 5 \%}$ & $\mathbf{1 0 \%}$ \\
\hline BWG $\%$ & $63.50^{\mathrm{a}} \pm 2.150$ & $19.75^{\mathrm{e}} \pm 0.830$ & $32.25^{\mathrm{d}} \pm 1.320$ & $47.88^{\mathrm{c}} \pm 1.340$ & $59.38^{\mathrm{b}} \pm 2.200$ \\
FI & $365.2^{\mathrm{a}} \pm 2.645$ & $225.2^{\mathrm{e}} \pm 1.841$ & $250.2^{\mathrm{d}} \pm 1.335$ & $295^{\mathrm{c}} \pm 1.749$ & $359.4^{\mathrm{b}} \pm 2.371$ \\
FER & $0.285^{\mathrm{a}} \pm 0.011$ & $0.143^{\mathrm{c}} \pm 0.005$ & $0.210^{\mathrm{b}} \pm 0.009$ & $0.265^{\mathrm{a}} \pm 0.012$ & $0.266^{\mathrm{a}} \pm 0.013$ \\
\hline
\end{tabular}

Values were expressed as mean \pm SD. Values within the same row having different superscript letters are significantly different at $\mathrm{P} \leq 0.05$. BWG: body weight gain, FI: feed intake, FER: feed efficiency ratio ,GCP: Garden cress powder. 
The best results were recorded for the group which was fed on $10 \%$ of GCP compared with control (+) group. These results confirmed the results of Windisch et al., (2007) who found that the increased feed intake with increasing level of GC may indicate its positive influence on appetite of the study animals and nutrient digestion. Also, This result is in consistence with that Beejmohun et al., (2014) who found that the total body weight $(\mathrm{g})$ in negative group showed a significant decrease as a result of induction of diabetes, whereas it increased with treating with cinnamon and cress seed methanol extract.

The data in Table (5) reflects the effect of GCP on kidney function of nephropathy diabetic rats level of urea, uric acid, creatinine and BUN in serum .These were used as biochemical marks to evaluate the renal injury. in diabetes, high glucose level for long time caused kidney damages and impairment in renal function resulting in elevation in the levels of urea, uric acid and creatinine which are considered as markers of renal dysfunction. From the table it can be observed that serum urea, creatinine, BUN and uric acid levels were significantly higher $(\mathrm{P} \leq 0.05)$ in positive control rats than that in normal control rats, This elevation in serum markers of kidney function found to be an indicator of decrease in glomerular filtration rate and tissue injury. These results are compatible with the findings of Jain and Somani, (2015). As well as, hyperglycemia caused a significant elevation in markers of renal dysfunction (Elizabeth and Harris, 2005). Data in the same table showed supplementation nephropathy diabetic rats with $10 \%$ of L.Sativum powder led to a significant $(\mathrm{P} \leq 0.05)$ reduction in levels of urea, uric acid creatinine and BUN levels compared to nephropathy diabetic rats supplemented with 5 and $7.5 \%$ of L.Sativum powder. These results are in agreement with Qusti, (2016) who showed that treating the diabetic rats with GC and cinnamon by different concentration of methanol extract,, caused a significant decrease in serum urea, creatinine, uric acid, and urine albumin. Also this result agrees with Kumar et al., (2014) who explicated this amelioration in renal function is due to the presence of flavonoids and steroidal compounds. These results confirmed the results of $\mathrm{Xu}$ et al., (2016) who found that flavonoids and phenolic compounds protected against diabetic nephropathy in STZ-induced diabetic rat improving blood urea nitrogen, creatinine and urine as well as kidney tissue damage, with a reduction in mitochondrial damage.

The data in Table (6) showed the effect of GCP on antioxidant enzymes as glutathione pyroxidase (GPX), superoxide dismutase (SOD), catalase (CAT), glutathione transferase (GST), total antioxidant capacity (TAC) and oxidant enzymatic as malondialdehyde (MDA) in serum of nephropathy diabetic rats. In biological system, there is a balance between the production and neutralization of (ROS). This balance is maintained by the presence of natural antioxidants and antioxidant enzymes such as catalase and glutathione peroxidase. The enhancement of lipid peroxidation or the decrease of antioxidant protection present in metabolic diseases or bad lifestyle can induce endothelial dysfunction (Lubrano and Balzan, 2015). There were significantly $(p \leq 0.05)$ increase of (MDA) level and decrease of (CAT), (GPX), (GST), (GSH.Px) and (SOD) activities in positive control rats comparing to normal control rats. These results are in agreement with Rajashkar et al., ( 2012) who mentioned that gentamicin increases the generation of ROS which led to reduce the activities of antioxidant enzymes and by depleting intracellular concentrations of GSH during the process of combating oxidative stress, which enhances lipid peroxidation. Also, Saddala et al., (2013) who reported that diabetes mellitus associated with a free radical induced lipid peroxidation and reduction in antioxidant enzymes activity.

On the other hand whereas feeding nephropathy diabetic rats with $10 \%$ of GCP led to improve the activity of CAT, SOD, GPX, GST and TAC as well as the level of MDA showed significant decrease $(p \leq$ 0.05 ) as compared with positive control rats. this positive effect of L.Sativum may be attributed to its antioxidant and free radical scavenging abilities.

Table 5. Effect of GCP on urea (mg/dl), uric acid $(\mathrm{mg} / \mathrm{dl})$ creatinine $(\mathrm{mg} / \mathrm{dl})$ and BUN of nephropathy diabetic rats

\begin{tabular}{cccccc}
\hline Groups & \multirow{2}{*}{$\begin{array}{c}\text { Normal } \\
\text { Control }\end{array}$} & $\begin{array}{c}\text { Positive } \\
\text { Control }\end{array}$ & $\mathbf{5 \%}$ & $\mathbf{G C P}$ \\
\cline { 3 - 6 } Parameter & & $34.75^{\mathrm{a}} \pm 1.351$ & $30.60^{\mathrm{b}} \pm 1.172$ & $26.32^{\mathrm{c}} \pm 1.012$ & $19.85^{\mathrm{d}} \pm 0.943$ \\
\hline Urea $(\mathrm{mg} / \mathrm{dl})$ & $19.22^{\mathrm{d}} \pm 0.712$ & $3.62^{\mathrm{a}} \pm 0.176$ & $2.51^{\mathrm{b}} \pm 0.121$ & $1.99^{\mathrm{c}} \pm 0.098$ & $1.52^{\mathrm{d}} \pm 0.071$ \\
Uric acid $(\mathrm{mg} / \mathrm{dl})$ & $1.41^{\mathrm{d}} \pm 0.057$ & $1.57^{\mathrm{a}} \pm 0.074$ & $1.36^{\mathrm{b}} \pm 0.063$ & $0.96^{\mathrm{c}} \pm 0.047$ & $0.50^{\mathrm{d}} \pm 0.024$ \\
Creatinine $(\mathrm{mg} / \mathrm{dl})$ & $0.53^{\mathrm{d}} \pm 0.011$ & $24.57^{\mathrm{a}} \pm 3.32$ & $23.95^{\mathrm{a}} \pm 0.85$ & $20^{\mathrm{b}} \pm 0.82$ & $15.37^{\mathrm{c}} \pm 0.65$ \\
BUN & $11.41^{\mathrm{d}} \pm 0.82$ & 2 &
\end{tabular}

Values were expressed as mean \pm SD. Values within the same row having different superscript letters are significantly different at $\mathrm{P} \leq 0.05$. BUN: Blood Urea Nitrogen ,GCP: Garden cress powder. 
Table 6. Effect of GCP on activities of (CAT), (SOD), (GPX), (GST), (TAC) and (MDA) enzymes of nephropathy diabetic rats

\begin{tabular}{|c|c|c|c|c|c|}
\hline \multirow{3}{*}{$\begin{array}{l}\text { Groups } \\
\text { Parameter }\end{array}$} & \multirow{3}{*}{$\begin{array}{l}\text { Normal } \\
\text { Control }\end{array}$} & \multicolumn{4}{|c|}{ Nephropathy Diabetic Rats } \\
\hline & & \multirow{2}{*}{$\begin{array}{l}\text { Positive } \\
\text { Control }\end{array}$} & \multicolumn{3}{|c|}{ GCP } \\
\hline & & & $5 \%$ & $7.5 \%$ & $10 \%$ \\
\hline $\mathrm{CAT}(\mathrm{mmoL} / \mathrm{L})$ & $76.74^{\mathrm{a}} \pm 2.897$ & $38.31^{\mathrm{d} \pm 1.876}$ & $56.00^{c} \pm 2.580$ & $63.74^{\mathrm{b}} \pm 2.145$ & $72.95^{\mathrm{a}} \pm 2.064$ \\
\hline SOD (U/L) & $55.75^{\mathrm{a}} \pm 1.985$ & $31.04^{\mathrm{d}} \pm 1.502$ & $43.33^{\mathrm{c}} \pm 1.951$ & $47.47^{b} \pm 2.135$ & $53.53^{\mathrm{a}} \pm 1.641$ \\
\hline GPX (ng/dl) & $83.53^{\mathrm{a}} \pm 2.225$ & $52.07^{\mathrm{d}} \pm 1.955$ & $61.72^{\mathrm{c}} \pm 2.035$ & $72.15^{\mathrm{b}} \pm 1.551$ & $80.78^{\mathrm{a}} \pm 2.277$ \\
\hline $\mathrm{GST}(\mathrm{mmoL} / \mathrm{L})$ & $1.94^{\mathrm{a}} \pm 0.461$ & $0.86^{\mathrm{b}} \pm 0.042$ & $1.40^{\mathrm{a}} \pm 0.095$ & $1.62^{\mathrm{a}} \pm 0.081$ & $1.90^{\mathrm{a}} \pm 0.069$ \\
\hline $\mathrm{TAC}(\mathrm{mmoL} / \mathrm{L})$ & $36.97^{\mathrm{a}} \pm 1.798$ & $19.94^{\mathrm{d}} \pm 1.947$ & $23.35^{\mathrm{c}} \pm 1.118$ & $28.12^{\mathrm{b}} \pm 1.356$ & $35.88^{\mathrm{a}} \pm 1.744$ \\
\hline $\mathrm{MDA}(\mathrm{mmoL} / \mathrm{L})$ & $17.17^{\mathrm{d}} \pm 0.808$ & $36.63^{\mathrm{a}} \pm 1.780$ & $31.21^{\mathrm{b}} \pm 1.511$ & $26.32^{\mathrm{c}} \pm 1.266$ & $19.11^{\mathrm{d}} \pm 0.905$ \\
\hline
\end{tabular}

Values were expressed as mean \pm SD. Values within the same row having different superscript letters are significantly different at $\mathrm{P} \leq 0.05$. CAT: catalase, SOD: superoxide dismutase, GPX: glutathione pyroxidase, GST: glutathione transferase TAC: total antioxidant capacity, MDA: malondialdehyde.

These results confirmed the results of Dugoua et al., (2007) who found that GC contain, among the natural dietary antioxidants and polyphenols in GC and have been shown to reduce oxidative stress via the inhibition of 5-lipoxygenase.

Also, Qusti et al., (2016) reported that treating the diabetic rats with $L$. sativum and cinnamon methanol extract significantly $(\mathrm{P}<0.001)$ increased the mean values of CAT, SOD, and GST compared with that of the positive control. This results indicate that the garden cress (L. sativum) contains high level of phenolic groups that cause scavenging of free radicals which is one of themajor antioxidation mechanisms to inhibit the chain reaction of lipid peroxidation.

Effect of GCP on glucose in blood and insulin in nephropathy diabetic rats are presented in Table (7). The nephropathy diabetic rats had higher $(\mathrm{P} \leq 0.05)$ blood glucose level than those in normal control during the experimental period. Wei et al., (2003) who found that STZ had a high affinity for binding to the glucose receptors present on the pancreatic $\beta$-cells, its ingestion relish the cytotoxic effect upon these cells and lead to dysfunction or cell death. This subsequently leads to alteration of insulin levels and blood glucose concentrations.However, the blood glucose level of nephropathy diabetic rats fed on GCP diets was significantly $(\mathrm{P} \leq 0.05)$ decreased by increasing GCP levels. The highest reduction in blood glucose level was found in nephropathy diabetic rats fed on $10 \%$ of GCP. These results confirmed the results of Qusti et al., (2016) who showed that treating the diabetic rats with $L$. sativum and cinnamon methanol extracts, significantly decreased the mean values of serum fasting blood sugar compared with the positive control. This result is consistence with Abdelwahab et al., (2014) who showed that using the aqueous $L$. sativum extract that can significantly reduce the blood glucose levels after a single or repeated administration. The strong hypoglycemic action of $L$. sativum extract is due to the presence of benzyl isothiocyanate (Prajapati et al., 2014).

On the other hand, nephropathy diabetic untreated rats (positive control) and nephropathy diabetic rats fed on GCP. diets had lower $(\mathrm{P} \leq 0.05)$ serum insulin level than the normal control rats during the experimental period. However, the serum insulin level was significantly $(\mathrm{P} \leq 0.05)$ increased by increasing the experiment period and GCP levels. The highest reduction of the serum insulin level was found in nephropathy diabetic rats fed on $10 \%$ of GCP. The results are compatible with Hamidpour et al., (2015) It also possesses insulin mimetic properties because its biologically active substances enhance glucose uptake by activating insulin receptor kinase activity, autophosphorylation of theinsulin receptor, and glycogen synthase activity. Also Eddouks et al., (2002) confirmed that GCP has the significant antidiabetic and cytoprotective activity in type I diabetic rats through phytochemicals study in it (flavonoids and glycosides) which have able to act and stimulate pancreatic $\beta$-cells to secrete insulin and enhance glucose metabolism.

Table 7. Effect of GCP on blood glucose and insulin of nephropathy diabetic rats

\begin{tabular}{|c|c|c|c|c|c|}
\hline \multirow{3}{*}{$\begin{array}{l}\text { Groups } \\
\text { Parameter }\end{array}$} & \multirow{3}{*}{$\begin{array}{l}\text { Normal } \\
\text { Control }\end{array}$} & \multicolumn{4}{|c|}{ Nephropathy Diabetic Rats } \\
\hline & & Positive & & GCP & \\
\hline & & Control & $5 \%$ & $7.5 \%$ & $10 \%$ \\
\hline Glucose(mg/dl) & $98^{\mathrm{e}} \pm 2.801$ & $233^{\mathrm{a}} \pm 2.774$ & $131^{\mathrm{b}} \pm 1.967$ & $119^{c} \pm 2.013$ & $103^{\mathrm{d}} \pm 1.547$ \\
\hline Insulin(ng/mg) & $14.16^{\mathrm{a}} \pm 2.33$ & $6.23^{\mathrm{d}} \pm 1.19$ & $9.48^{\mathrm{c}} \pm 1.25$ & $10.43^{\mathrm{b}} \pm 2.16$ & $10.71^{\mathrm{b}} \pm 2.12$ \\
\hline
\end{tabular}

Values were expressed as mean \pm SD. Values within the same row having different superscript letters are significantly different at $\mathrm{P} \leq 0.05$. 
Table 8. Effect of GCP on Liver functions ; aspartate amino transaminase (AST), alanine aminotransferase (ALT), And alkaline phosphatase (ALP) of nephropathy diabetic rats

\begin{tabular}{cccccc}
\hline \multirow{2}{*}{ Groups } & Normal & \multicolumn{4}{c}{ Nephropathy Diabetic Rats } \\
\cline { 3 - 6 } Parameter & Control & Positive & \multicolumn{3}{c}{ GCP } \\
\hline AST(U/L) & $101.2^{\mathrm{e}} \pm 2.530$ & $181.2^{\mathrm{a}} \pm 2.851$ & $152.1^{\mathrm{b}} \pm 2.532$ & $135.3^{\mathrm{c}} \pm 1.785$ & $112.1^{\mathrm{d}} \pm 2.160$ \\
ALT(U/L) & $48.01^{\mathrm{d}} \pm 1.178$ & $67.20^{\mathrm{a}} \pm 1.950$ & $61.20^{\mathrm{b}} \pm 1.752$ & $59.1^{\mathrm{b}} \pm 1.501$ & $52.1^{\mathrm{c}} \pm 1.275$ \\
ALP(U/L) & $190.1^{\mathrm{e}} \pm 2.480$ & $297.1^{\mathrm{a}} \pm 3.133$ & $215.2^{\mathrm{b}} \pm 2.057$ & $209.1^{\mathrm{c}} \pm 1.200$ & $198.3^{\mathrm{d}} \pm 1.791$ \\
\hline
\end{tabular}

Values were expressed as mean \pm SD. Values within the same row having different superscript letters are significantly different at $\mathrm{P} \leq 0.05$. AST: aspartate amino transaminase, ALT: alanine aminotransferase and ALP: alkaline phosphatase

Data of Table (8) indicate the effect of GCP on serum levels of Liver functions (AST, ALT and ALP enzymes) of nephropathy diabetic rats. The obtained results showed the gentamicin and STZ can cause alterations in the level of hepatic biochemical markers throw increasing the serum levels of aspartate amino transaminase (AST), alanine aminotransferase (ALT), and alkaline phosphatase (ALP) compare with normal rats. Those data were in agreement with Ademiluyi et al., (2013) who demonstrated that GM administration significantly damaged liver cells as manifested by a large increase in ALT and AST activities and total bilirubin level. Moreover, it caused a marked decrease in total protein concentration indicating a failure in liver synthetic capacity caused by GM administration. A significant decrease $(\mathrm{P} \leq 0.05)$ in the elevated level of liver enzymes was noticed in treated groups when compared with positive control rats. The best values of liver enzymes were recorded to $10 \%$ of GCP compare to $(+)$ control rats. These data are in agreement with those of Pandit et al., (2012) and Zamzami et al., (2019) who confirmed that concurrent treatment of rabbits injured with $\mathrm{CCl} 4$ for 5 and 10 weeks with $L$. sativum seeds led to significantly repaired their liver enzymes such as elevation of total protein and albumin improved with decrease level of globulin.

\section{CONCLUSION}

The present study showed that the GCP Lepidium Sativum efficiently regulate blood glucose and improves disruption of kidney functions abnormalities associated with diabetes in STZ and gentamicin induced nephropathy diabetic rats possibly by virtue of various essential antioxidant, antidiabetic compounds. GC can thus contribute towards prevention and management of diabetes mellitus and nephropathy and it associated complications.

\section{REFERENCE}

Abdelwahab, S. I, A. A. Mariod and M. M. E. Taha. 2014. Chemical composition and antioxidant properties of the essential oil Journal of Chemistry,.of CinnamomumaltissimumKosterm. (Lauraceae),Arabian.
Ademiluyi, A.O., G. Obah, T.R. Owoloye. 2013. Modulatory effects of inclusion of garlic (Allium sativum) on gentamicin induced hepatotoxicity and oxidative stress in rats. Asian Pac J Trop Biomed.3(6): 470-475.

Ait-Yahia, O., F. Perreau, S. Bouzroura, Y. Benmalek, T. Dob and T. Belkebir. 2018.Chemical composition and biological activities of nbutanol extract of LepidiumsativumL. (Brassicaceae) seed. Tropical J. Pharm. Res.17 (5): 891-896.

AOAC. 2005.Official Methods of Analysis ofthe Association of Official AnalyticalChemists, 18th Ed. Gaithersburg, Maryland,USA. AOAC Int.

AOAC .2010. Official Methods of the Association of Official Analytical Chemists. $15^{\text {th }}$ ed. Wilson boulevardarling. Virginia. 22201.

Artimage, G.Y. and W.G. Berry.1987.Statistical Methods 7th Ed. Ames, Iowa State University Press:39-63.

Beejmohun,V., M. Peytavy-Izard and C. Mignon.2014. Acute effect of Ceylon cinnamon extract on postprandial glycemia:alpha-amylase inhibition, starch tolerance test in rats, and randomized crossover clinical trial in healthy volunteers," BMC Complementary and Alternative Medicine. 14(1): 351-370.

Bryan, R.M., N. S. Shailesh, K. Jill, M. Winkler, F. V. Steven and L. Roque. 2009.Evangelista. Composition and physical properties ofcress (Lepidiumsativum L.) and field pennycress (Thlaspiarvense L.) oils, Indust Crops Prod.30:199-205.

Chapman, D.C., R. Castilla, and J. A. Campbell. 1959. Evaluation of protein in food: A Method for the determination of protein efficiency ratio. Can. J.Biochem. Physiol. 37: 679-688.

Chauhan, K., Sh. Sharma, N. Agarwal, S. Chauhan and B. Chauhan. 2012.A Study on Potential Hypoglycemic and Hypolipidemic Effects of LepidiumSativum(Garden Cress) In Alloxan Induced Diabetic Rats. Am.Journal of Pharm Tech Research. 2.(3): 523-535.

Cordero-Herrera, M. M. Á., L. Goya and S. Ramos. 2015. Cocoa intake ameliorates hepatic oxidative stress in young Zucker diabetic fatty rats. Food Research International. 69: 194-201.

Diego, S. 2011. Oxiselect TM Catalase Activity Assay Colorimetric. Cell Biolabs, Inc.: 1-9. 
Doke, S.C. and R. Guha. 2017.Quality assessment of sweet snack from garden cress (LepidiumsativumL.) seeds-An unexplored health grain. J. Food Proc. 42:1-6.

Dontabhaktuni, A., D. R. Taft and M. Patel.2016.Gentamicin renal excretion in rats: Probing strategies to mitigate drug-induced nephrotoxicity. Pharmacol, Pharm. 7: 43-55.

Dugoua, J., D. Seely and D. Perri. 2007. From type 2 diabetes to antioxidant activity: a systematic review of the safety and efficacy of common and cassia cinnamon bark, Canadian Journal of Physiology and Pharmacology. 85.(9):837847.

Eddouks, M., M. Maghrani, A. Lemhadri, M. L. Ouahidi and H. Jouad. 2002.Ethnopharmacological survey of medicinal plants used for the treatment of diabetes mellitus, hypertension and cardiac diseases in the SouthEast region of Morocco (Tafilalet). Journal of Ethnopharmacology. 82(2-3): 97-103.

Eddouks, M., M. Maghrani, N.A. Zeggwagh and J.B. Michel. 2005.Study of the hypoglycemic activity of LepidiumsativumL. aqueous extract in normal and diabetic rats. J Ethno.97(2): 391-395.

Elizabeth, H. and M. D. Harris. 2005. Elevated liver function tests in type 2 diabetes. Clin Diabetes. 23: 115-119.

Fossati, P., L. Prencipe and G. Berti. 1980. Use of 3, 5-dichloro-2-hydroxybenzenesulfonic acid/4-aminophenazone chromogenic system in direct enzymic assay of uric acid in serum and urine. Clinical Chemistry. 26 (2): 227-231.

Gokavi, S.S., N. G. Malleshi and M. Guo. 2004. Chemical Composition of Garden Cress (Lepidium sativum) seeds and its fractions and use of bran as a functional ingredient, Plant Foods Human Nutr. 59:105-111.

Goupy, P., M. Hugues, P. Biovin and M.J. Amiot. 1999. Antioxidant composition and activity of barley (Hordeum vulgare L.) and malt extracts of isolated phenolic compounds. J. Sci. Food Agric., 79: 1625-1634.

Ha, H. and H. B. Lee. 2000. Reactive oxygen species as glucose signaling molecules in mesangial cells cultured under high glucose, Kidney International. Supplement.58.(77): 19-25.

Hamidpour,R. M., S. Hamidpour and M. Shahlari. 2015. Cinnamon from the selection of traditional applications to its novel effects on the inhibition of angiogenesis in cancer cells and prevention of Alzheimer's disease, and a series of functions such as antioxidant, anticholesterol, antidiabetes, antibacterial, antifungal, nematicidal, acaracidal, and repellent activities, Journal of Traditional and Complementary Medicine.5(2): 66-70.

Hegsted, D. M., R. C. Mills and C. A. Elvehjen. 1941. Choline in chicks. J. Bio. Chem. 138: 459-478.

Henry, R. J. 1974.Clinical Chemistry principles and Techniques 2nd Ed, Harper and Publishers, New York, Philadelphia.

Hovind,P. L., K. Tarnow and M. Rossing. 2003. Decreasing incidence of severe diabetic microangiopathy in type 1 diabetes, Diabetes Care. 26 (4): 1258-1264.
I.F.C.C. 1983. Methods for the measurement of catalytic concentration of enzymes - Part 5: IFCC, methods for alkaline phosphatase. J. Clin. Chem. Clin. Biochem. 21:731-748.

Jain, D. and R. Somani. 2015.Silibinin: A bioactive flavanone in milk thistle ameliorates gentamicin induced nephrotoxicity in rats. Pharmacologia, 6: 38-44.

Jeyanthi, T. and P. Subramanian. 2009. Nephroprotective effect of withaniasomnifera: a dose-dependent study, Renal Failure. 31. (9): 814-821.

Kahn, S. E., M. E. Cooper and S. Del Prato. 2014. Pathophysiology and treatment of type 2 diabetes: perspectives on the past, present, and future. Lancet, 383(9922):1068-1083.

Kittell, F. 2012.Diabetes Management, In Thomas LK, Othersen JB. Nutrition Therapy for Chronic Kidney Disease. CRC. Press., p. 198.

Koracevic, D., G. Koracevic, V. Djordjevic, S. Andrejevic and V. Cosic. 2001. Method for the measurement of antioxidant activity in human fluids. J. Clin. Pathol. 54: 356-361.

Kumar, K., A. Issac, E. Ninan, R. Kuttan, and B. Maliakel. 2014. Enhanced anti-diabetic activity of polyphenol-rich de-coumarinated extracts of Cinnamomum cassia. Journal of Functional Foods. 10:54-64.

Lubrano, V. and S. Balzan. 2015.Enzymatic antioxidant system in vascular inflammation and coronary artery disease. World J. Exp. Med. 5(4): 218-224.

Maier, U.H., H. Gundlach and M.H. Zenk. 1998. Seven imidazole alkaloids from Lepidiumsativum. Phytochemistry. 49: 1791-1795.

Nale, L. P., P. R. More, B. K. More, B. C. Ghumare, S. B. Shendre and C. S. More. 2012. Protective effect of Carica Papaya L. seed extract in gentamicin induced hepatotoxicity and nephrotoxicity in rats. Int. J. Pharm. Bio. Sci. (3): 508-515.

Ohkawa, H., W. Ohishi and K. Yagi. 1979. Assay for lipid peroxides in animal tissues by thiobarbituric acid reaction. Anal. Biochem. 95: 351-358.

Omolaoye, T. S., T. Bongekile, S. S. Skosana and D. Plessis. 2018. Diabetes mellitus-induction: Effect of different streptozotocin doses on male reproductive parameters. Acta, Histochemica. 120: 103-109.

Pandit, A., T. Sachdeva and P. Bafna. 2012. Drug-Induced Hepatotoxicity: A Review. Journal of Applied Pharmaceutical Science. 2(5): 233-243.

Philip, D.M. 1994.Clinical chemistry in diagnosis and treatment. 6th Ed., London. New York. New Delhi.

Prajapati, V. D., P. M. Maheriya, K. Jani, P. D. Patil and B. N. Patel. 2014.Lepidiumsativum Linn: a current addition to the family of mucilage and its applications," International Journal of BiologicalMacromolecules.65:72-80. 
Qusti, S., H.A. El Rabey and S.A. Balashram. 2016. The Hypoglycemic and Antioxidant Activity of Cress Seed and Cinnamon on Streptozotocin Induced Diabetes in Male Rats. EvidBased Complement Alternat Med.:5614564.

Rajashekar, V., E. U. Rao and P. Srinivas. 2012. Biological activities and medicinal properties of gokhru (Pedalium murex L.) Asian Pac. J. Trop. Biomed. 2: 581-585.

Reeves, P. G., F. H. Nielsen and G. C. Fahey.1993. AIN-93 purified diets for laboratory rodents: Final report of the American Institute of Nutrition ad Hoc Writing Committee on the reformulation of the AIN-76A rodent diet. J. Nutr., 123: 1939-1951.

Saddala, R. R., L. Thopireddy, N. Ganapathi and S. R. Kesireddy. 2013.Regulation of cardiac oxidative stress and lipid peroxidation in streptozotocin-induced diabetic rats treated with aqueous extract of Pimpinellatirupatiensis tuberous root. Exp. Toxicol. Pathology. 65: 15-19.

Satoh K. 1978. Serum lipid peroxide in cerebrovascular disorders determined by a new colorimetric method. Clinica chimica acta; international journal of clinical chemistry. 90(1): 37-43.

Sethiya, N., A. Trivedi and S. Mishra. 2014. The total antioxidant content and radicalscavenging investigation on 17 phytochemicalfrom dietary plant sources used globally asfunctional food. Biomedicine and Preventive.Nut. 4(3): 439-444.

Shail, D., K.N. Manjari and L.N. Gupta. 2016. Nutritional importance of LepidiumsativumL. (Garden cress/ Chandrashoor): A Rev. J. Pharm. and Anal. Res. 5 (1): 152-160.

Sharma,B. G., R. Viswanath, Salunke and P. Roy. 2008. Effects of flavonoid-rich extract from seeds of Eugenia jambolana (L.) on carbohydrate and lipid metabolism in diabetic mice, Food Chemistry. 110. ( 3): 697-705.

Sun, v. I., W. Larry, A. Oberely and V. Ving. 1988. A simple method for clinical assay of superoxide dismutase. Clin. Chem. 34 (3):497-500.

Tietz, N. 1986. Textbook of Clinical Chemistry, WB Saunders, Philadelphia, Pa, USA.

Tran, L., A. Zielinski, A.H. Roach, J.A. Jende, A.M. Householder, E.E. Cole, S. Atway, M. Amornyard, M.L. Accursi and S.W. Shieh. 2015. Pharmacologic treatment of type 2 diabetes oral medications. Ann. Pharmacother. 49:540-556.
Trinder, P. 1969. Determination of blood glucose using an oxide seperoxidase system with a non-carcinogenicchromogen. Journal of Clinical Pathology. 22 (2): 158-161.

Wang, G. G., X. H. Lu, W. Li, X. Zhao and C. Zhang. 2011. Protective Effects of Luteolin on Diabetic Nephropathy in STZ-Induced Diabetic Rats. Evidence-based complementary and alternative medicine: (323171):7.

Wei, M., L. Ong, M. T. Smith, F. B. Ross, K. Schmid, A. J. Hoey, D. Burstow and L. Brown. 2003. The streptozotocin-diabetic rat as a model of the chronic complications of human diabetes. Heart Lung Circ. 12 (1): 44-50.

Windisch, W., K. Schedle, C. Plitzer and A. Kroismayr. 2007.Use of phytogenic products as feed additives for swine and poultry. J AnimSci 86:140-148.

World Health Organization. 2016. Definition and diagnosis of diabetes mellitus and intermediate hyperglycaemia: http:// whqlibdoc. Who.int/ publications/ 2006/ 9241594934-eng.

Xu, X., N. Zheng, Z. Chen, W. Huang, T. Liang and H. Kuang. 2016. Puerarin, isolated from Puerarialobata (Willd.), protects against diabetic nephropathy by attenuating oxidative stress. Gene.15;591(2):411-6.

Yanardağ, R., S. Bolkent, O. Karabulul-Bulan and S. Tunali. 2003. Effects of vanadyl sulfate on kidney in experimental diabetes. Biol. Trace. Elem. Res. 95:73-85.

Yokoyama, H. M., T. Okudaira and S. Otani. 2000. Higher incidence of diabetic nephropathy in type 2 than in type 1 diabetes in early-onset diabetes in Japan, Kidney International.58.(1):302-311.

Yound, D. S. 1975. Determination of GOT. J. Clin. Chem. 21:1- 6 .

Zamzami, M.A., O.A.S. Baothman, F. Samy and M.K. AboGolayel. 2019.Amelioration of CCl4-Induced Hepatotoxicity in Rabbits by Lepidiumsativum Seeds. Evidence-Based Complementary and Alternative Medicine., Article ID 5947234: 1-17.

Zhao, Y., Y. Xue, T.D. Oberley, K.K. Kiningham, S.M. Lin. 2001. Overexpression of manganese superoxide dismutase suppresses tumor formation by modulation of activator protein-1 signaling in a multistage skin carcinogenesis model. Cancer Res 61: 6082-6088.

Zia-Ul-Haq, M., S., L. Ahmad, T. Calani, D. Mazzeo, N. Del Rio, and D. Pellegrini. 2012. Compositional study and antioxidant potential of Ipomoea hederaceaJacq. and Lepidium sativum seeds. Molec., 17: 10306-10321. 


\section{الملخص العربي}

دراسة التأثير العلاجي المحتمل لنبات حب الرشاد على الفئران المصابة باعتلال الكلى والسكرى: دراسات بيولوجية وكيموحيوية

أمل ناصف زكي ناصف و بسمة رمضان محمد خطيب

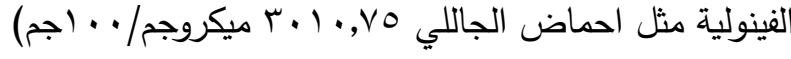

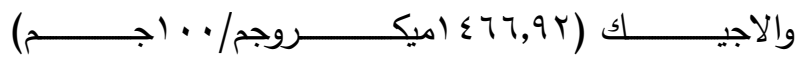

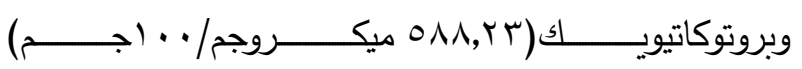

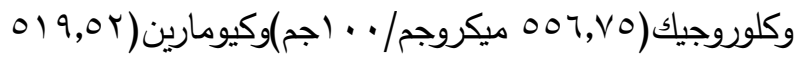

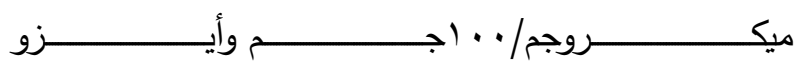

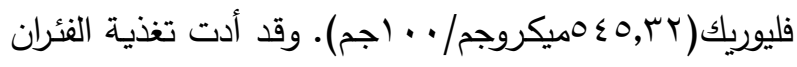
المصابة بالاعتلال الكلوي بالسكري على نظام غذائي يومي

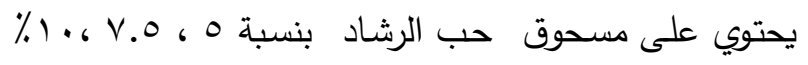
إلى انخفاض ملحوظ في مستويات الجلوكوز ووظائف الكبد

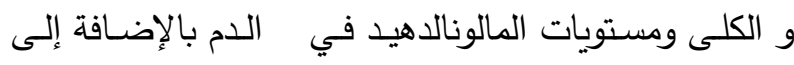
ارتفاع في نشاط مستويات الجلوتاثيون ترانسفيريز والسوبر اوكسيديز ديسميوتيز والقدرة الكلية المضـادة للأكسدة والجلوتاثيون بيروكسيديز والكتالييز ومستويات الأنسولين في الدم مقارنة بالمجموعة الضابطة الموجبة. وكانت المجموعة المضاف لها مسحوق حب الرشاد بنسبة ـ ٪\%. أكثر فاعلية في تحسين المعايير السـبقة. في الختام ، خلصت الدراسـة إلى أن مسحوق رشاد لله تأثيرات قوية على سكر الدم ويحسن التلف الكلوي الناجم عن الجنتاميسين في الفئران المصـابة بداء السكري. لذلك فمن المستحسن إضـافة حب الرشاد إلى النظام الغذائي اليومي لمرضى الكلى لـ لـن

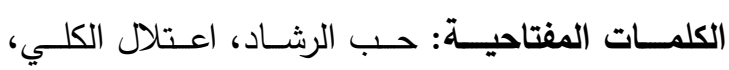

الستربتوزوتوسين، الجنتاميسين، الجلوكوز ، وظائف الكلى ,

مضادات الاكسده, الانسولين , اليوريا.
يعتبر حب الرشاد نباتًا طبيًا مهمًا وينمو على نطاق واسع في العديد من البلدان بما فيها مصر ونظرا لمحتواه العالي

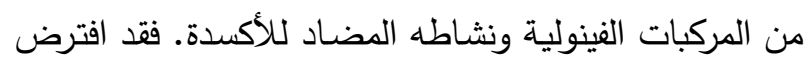
أنه يمكن أن يكون غذاء وظيفيًا. في هذا البحث، تم تقييم التأثيرات العلاجية المحتملة لمسحوق حب الرشاد على اعتلال الكلية المستحث بالجنتاميسين في الجرذان المصسابة بداء

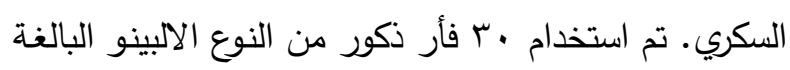

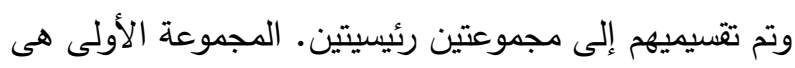

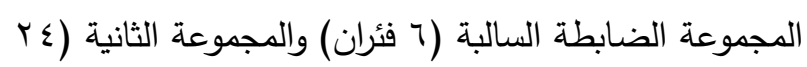

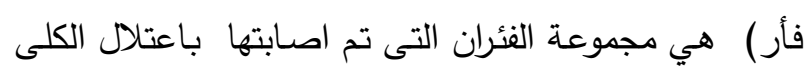
والسكرى والتى أعطيت جرعة واحدة من الستربتوزوتوسين عن بـ هن

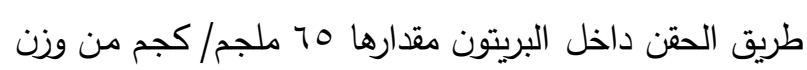
الجسم، ثم بعد ذلك تمت الإصـابة باعتلال الكلى للفئران المصابة بالسكر عن طريق حقنها بالجنتاميسين بجرعة يومية مقدارهاهم ملجم / كجم من وزن الجسم لمدة 1 أيام منتالية. وقسمت مجموعة الفئران المصابة باعتلال الكلى والسكري إلى منى أربع مجموعات فرعية (7 فئران بكل منها) على النحو التالي:

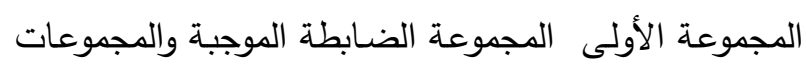
الثانية, الثالثة والرابعة: تتاولت الوجبة القياسية مضافا لها لهابله

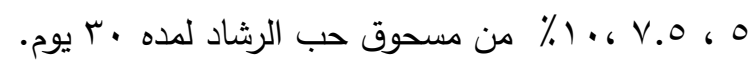
وقد أظهرت النتائج أن مسحوق حب الرشاد يحتوي على نسبة

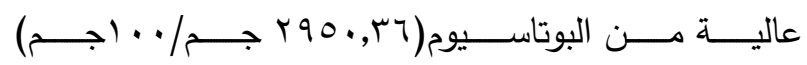

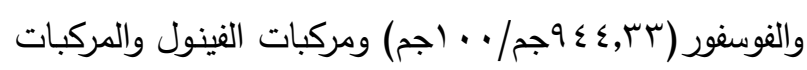

